Віктор Шевченко, Ігор Кондратенко, Олександр Гусев, Олег Хоменко, Костянтин Тительмаср

\title{
ОЦНКА ТОЧНОСТІ МОДЕЛІ ДВОШАРОВОЇ КОТУШКИ ІНДУКТИВНОСТІ ДЛЯ БЕЗДРОТОВОЇ ПЕРЕДАЧІ ЕНЕРГІЇ ЗА ДОПОМОГОЮ МЕТОДУ СКІНЧЕНИХ ЕЛЕМЕНТІВ
}

\begin{abstract}
Актуальність теми дослідження. Ця тема є актуальною у зв'язку зі зростаючим попитом та інтересом до бездротових зарядних пристроїв з боку дослідників та користувачів.

Постановка проблеми. У процесі розробки систем бездротової передачі енергії дослідникам потрібно проектувати котушки індуктивності з різною точністю параметрів відповідно до поставлених завдань. Тому необхідно знати, наскільки точно можна розробити модель котушки індуктивності в одному з популярних пакетів.

Аналіз останніх досліджень і публікацій. Були розглянуті останні публікачї про різні програми, що використовуються для моделювання електромагнітних прочесів. 3 джерел про будову котушок індуктивності зібрано необхідну інформацію для аналізу й порівняння.

Виділення недосліджених частин загальної проблеми. Досі не було зібрано та узагальнено у зручному для порівняння вигляді інформачію про різні структури, будову і складові котушок індуктивності для бездротової передачі енергії. Питанню точності моделей котушок індуктивності у програмах, щьо трунтуються на методі скінчених елементів, також не приділялось достатньо уваги.

Постановка завдання. Основне завдання полягає в оцінці точності моделювання двох однакових двошарових котушок для бездротової передачі електроенергї у відповідній програмі за методом скінчених елементів.

Виклад основного матеріалу. Проведено аналіз структури індуктивностей, а саме геометрії обмотки, форми й матеріалу феритового осердя та його ролі екранування електромагнітного поля та направлення потоку магнітної індукцї̈ на значення індуктивності. Розроблено та запропоновано спрощену модель індуктивності й визначено ї̈ електромагнітні параметри.

Висновки відповідно до статті. Підтверджено результати моделювання двошарових котушок, чим доведено, що ANSYS EM Suite є точним та надійним інструментом і навіть спрощені моделі індуктивностей цілком задовольняють вимоги інженерів та дослідників.

Ключові слова: бездротова передача енергї̈; індуктивна передача енергї̈; геометрія котушки; магнітний потік; форма осердя; екранування; моделювання методом скінчених елементів, двошарова котушка.

Рис.: 4. Табл.: 2. Бібл.: 19.
\end{abstract}

Актуальність теми дослідження. При зростаючому інтересі до бездротової передачі енергії та технічних вимог до бездротових зарядних пристроїв актуальною $є$ тема про використання програмних засобів для моделювання електромагнітної частини системи бездротової передачі енергії.

Постановка проблеми. При проектуванні котушки індуктивності визначення певних геометричних та електромагнітних параметрів аналітичними методами може бути об'ємним і складним завданням. Для канонічних форм котушок використовуються емпіричні та приблизні формули. Складні форми котушок іноді подають як комбінацію канонічних форм, що не завжди приводить до достовірного результату. Тому для оптимізації та дослідження різних параметрів котушок індуктивності доцільно звернутись до чисельних методів розрахунку електромагнітного поля. Найбільшого поширення нині набув метод скінчених елементів (МСЕ), який реалізовано у відомих прикладних комерційних і академічних пакетах. Такі пакети прикладних програм пристосовані для розв'язку різноманітних задач, які описуються диференціальними рівняннями з граничними умовами різного ступеня формалізації, що, безперечно, передбачає певну точність результатів розрахунку параметрів індуктивності котушки. Отже, важливим та актуальним завданням $є$ потреба з'ясувати, яка точність визначення параметрів може бути в моделі котушок індуктивності з більш складною геометрією.

Аналіз останніх досліджень і публікацій. Дослідники та інженери переважно використовують такі комерційні та академічні версії пакетів на основі MCE: ANSYS Maxwell [1-5], FEMM [2], [6-8], COMSOL [9; 10], 3D JMAG [11], [12], ANSOFT [13], Infolytica Magnet [14] та багато інших. Також для повного прогнозування роботи розроблених котушок виконується їх термічне моделювання [6]. Майже в усіх перелічених роботах не приділяється великого значення оцінці точності моделей.

(C) Шевченко В. О., Кондратенко І. П., Гусев О. О., Хоменко О. Б., Тительмаєр К. О., 2019 
TECHNICAL SCIENCES AND TECHNOLOGIES

У статті [2] проведено порівняння моделі котушок індуктивності у програмах FEMM та ANSYS. Зазначено, що для простих одношарових круглих котушок індуктивності при потужності 5 кBA в ANSYS можна досягти вдвічі кращої точності визначення значень індуктивності. Показано, що похибка обчислення для магнітного поля порівняно з експериментальним вимірюванням за допомогою промислового приладу становить близько $10 \%$ для обох пакетів [2].

B ANSYS є можливість побудови та дослідження електричної схеми із застосуванням попередньо змодельованих котушок. Але не враховано певні важливі параметри електронних компонентів, перш за все це стосується напівпровідників. Тому визначення втрат потужності всієї схеми, електричних параметрів може бути з похибкою, що більша за інженерну точність. У роботі [2] зазначено, що похибка для загальних втрат потужності становила близько 15 \% при максимально точних налаштуваннях.

Академічні навчальні версії FEMМ мають простий та інтуїтивний інтерфейс і дозволяють імітувати прості моделі та бачити обмежену кількість електромагнітних параметрів лише у двовимірній постановці. Пакети ANSYS, COMSOL - це потужні універсальні інструменти 3 комерційною ліцензією та відносно складним розвинутим інтерфейсом. Оскільки об'єктом дослідження є двошарові котушки індуктивності з подвійним намотуванням, потрібен потужний і досконалий інструмент для побудови моделі та визначення основних електромагнітних параметрів.

Постановка завдання. Основне завдання полягає в оцінці точності моделювання двох однакових двошарових котушок для бездротової передачі електроенергії у відповідній програмі за методом скінчених елементів.

Виклад основного матеріалу. Геометрія котушки, матеріал осердя та екранування.

У цій статті під бездротовою передачею енергії (БПЕ) мається на увазі індуктивний спосіб передачі енергії (ICПЕ).

Структура котушки для бездротової передачі електроенергії (БПЕ) здебільшого складається 3 обмотки 3 мідного дроту, феритового осердя, екрануючої пластини (рис. 1) [15]. Добре відомо, що використання літцендрату замість звичайного мідного дроту з однаковим поперечним перерізом значно збільшить площу поверхні i, отже, зменшить скін-ефект на середніх і високих частотах [16]. Використання літцендрату також дозволяє зменшити масогабаритні параметри котушок індуктивності, покращуючи добротність та зменшуючи активний опір [15].

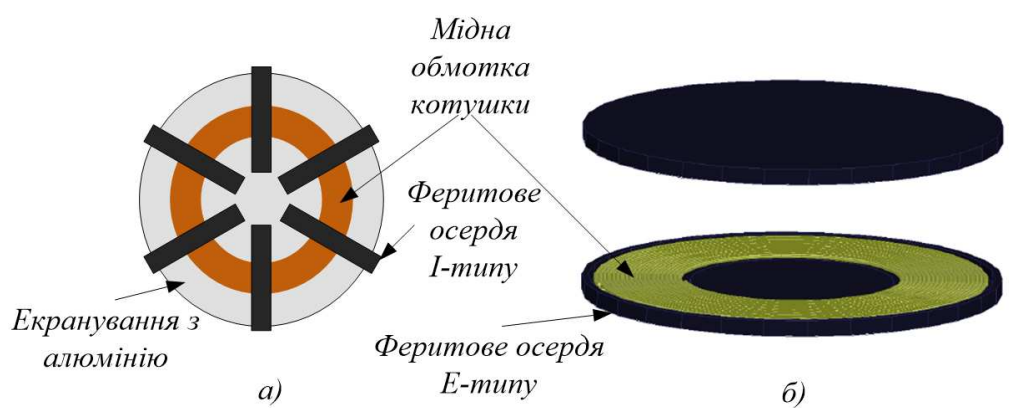

Рис. 1. Структура котушки індуктивності для БПЕ:

a - типова будова круглої котушки для електричних автомобілів;

Джерело: [15]. б - круглі котушки з феритовим осердям Е-типу

Найчастіше використовуються круглі, квадратні та прямокутні форми котушок [6]. Геометрія круглої котушки забезпечує більший коефіцієнт магнітного зв'язку на одиницю площі поверхні [3]. Крім того, відомо, що на високих частотах опір провідника, зігнутого під прямим або гострим кутом, буде більшим. Останнє пояснює перевагу круглої котушки 
перед прямокутною, оскільки ефективність передачі енергії здебільшого визначається добутком добротності індуктивності $(Q)$ і коефіцієнта магнітного зв'язку $k$ [10]. Це і призводить до підвищення ефективності передачі енергії круглою котушкою [4; 5; 10].

Що стосується інших, більш складних і модифікованих форм котушок, вони представлені в [3; 17]. Було проведено їх порівняння, переваги та недоліки і рекомендації щодо застосування були відмічені та показані в табл. 1. За даними досліджень [3; 17], найкращими формами котушки є кругла та подвійна квадратна (Double-D Quadrature (DDQ)). Найкращий результат для щільності магнітного потоку отримано для геометрії DDQ, не набагато гірший результат - круглої геометрії [17].

Осердя необхідне для підвищення коефіцієнта зв'язку, індуктивності, взаємної індуктивності та добротності між котушками. Також осердя зменшує розповсюдження магнітного поля за межами взаємодії котушок. Для круглих котушок найпоширенішими формами осердь можуть бути плоска пластина, осердя Е-типу та U-типу [15]. Плоска пластина має найпростішу форму й добре відповідає конструктивно-функціональним вимогам [4]. У промисловості частіше використовують феритове осердя прямокутної форми, як більш універсальне та просте у виробництві.

Матеріал для екранування та спрямування магнітного потоку повинен забезпечувати хороший коефіцієнт зв'язку, утримувати й направляти магнітний потік, захищати від електромагнітного випромінювання [3]. Ферит $є$ найбільш підходящим матеріалом через високу відносну проникність та малі втрати на високих частотах [3]. Одним із недоліків феритової структури великих розмірів є крихкість матеріалу та значне збільшення ваги всієї електромагнітної частини системи БПЕ.

Електромагнітне поле також змінюється зі збільшенням робочої частоти та потужності передачі. Магнітне поле індукує вихрові струми в металевому об'єкті, який розташований на котушці приймача або поблизу нього, що призводить до додаткових втрат та можливого нагрівання об'єкта. Екранування мінімізує розповсюдження магнітного поля та зменшує його вплив на навколишній матеріал і тканини людини.

Екранування може бути з магнітних матеріалів (фериту) або металевих матеріалів (найчастіше з алюмінію), пасивним та активним [18]. Наприклад, для електромобілів пасивне екранування алюмінієвою пластиною $є$ найпоширенішим методом зниження інтенсивності електромагнітного поля поза робочої зони завдяки простоті, надійності та відносно невисокій вартості [19]. Проте у випадку передачі потужності до декількох сотень ват екранування з фериту буде більш доречним, i його буде достатньо.

Результати проаналізованих джерел літератури [1-19] узагальнені в порівняльній табл. 1.

Таблиця 1

Порівняння основних складових структури котушки

\begin{tabular}{|c|c|c|c|}
\hline Параметр & $\begin{array}{c}\text { Порівняльна } \\
\text { пара }\end{array}$ & Переваги & Недоліки \\
\hline 1 & 2 & 3 & 4 \\
\hline \multirow{2}{*}{$\begin{array}{l}\text { Форма об- } \\
\text { мотки ко- } \\
\text { тушки }\end{array}$} & Кругла & \multicolumn{2}{|c|}{$\begin{array}{l}\text { Особливості: } \\
\text { 1) Найпростіша структура для виготовлення; } \\
\text { 2) Всенаправлені характеристики [17]; } \\
\text { 3) Мінімальні втрати провідності у дротах обмотки [10]. }\end{array}$} \\
\hline & $\begin{array}{l}\text { Прямокутна і } \\
\text { квадратна }\end{array}$ & \multicolumn{2}{|c|}{$\begin{array}{l}\text { Особливості: } \\
\text { 1) Максимальна площа передачі [10]; } \\
\text { 2) Симетричні характеристики [17]; } \\
\text { 3) Добре підходить для пристроїв прямокутної форми, наприклад смар- } \\
\text { тфонів [18]. }\end{array}$} \\
\hline
\end{tabular}


Закінчення табл. 1

\begin{tabular}{|c|c|c|c|}
\hline 1 & 2 & 3 & 4 \\
\hline \multirow{2}{*}{$\begin{array}{l}\text { Конфігу- } \\
\text { рація ко- } \\
\text { тушки }\end{array}$} & $\begin{array}{l}\text { Проста } \\
\text { (кругла, пря- } \\
\text { мокутна, } \\
\text { квадратна) }\end{array}$ & $\begin{array}{l}\text { 1) Стандартна форма, проста у виробництві; } \\
\text { 2) Односторонній характер схеми потоку } \\
\text { сприяє зменшенню витоку потоку [5; 4]; } \\
\text { 3) Найвищий коефіцієнт зв'язку при зміні } \\
\text { відстані між котушками }[10 ; 17] .\end{array}$ & $\begin{array}{l}\text { Вузький ефективний робочий } \\
\text { діапазон при осьовому зсуві } \\
{[17] .}\end{array}$ \\
\hline & $\begin{array}{l}\text { Складна } \\
\text { (DD,DDQ) }\end{array}$ & $\begin{array}{l}\text { 1) Висока ефективність при великому діа- } \\
\text { пазоні осьового зміщення [17]; } \\
\text { 2) Більш рівномірний розподіл магнітного } \\
\text { поля [3]; } \\
\text { 3) Краща густина магнітного потоку [17]. }\end{array}$ & $\begin{array}{l}\text { Складна у виготовленні та } \\
\text { об’ємна обмотка. }\end{array}$ \\
\hline $\begin{array}{l}\text { Матеріал } \\
\text { осердя }\end{array}$ & $\begin{array}{l}\text { Ферит, } \\
\text { порівняно з } \\
\text { металами та } \\
\text { сплавами }\end{array}$ & $\begin{array}{l}\text { 1) Висока відносна магнітна проникність [3]; } \\
\text { 2) Низькі втрати на високих частотах [10]; } \\
\text { 3) Котушка має більшу індуктивність, вза- } \\
\text { ємоіндуктивність та коефіцієнт зв’язку [3]. }\end{array}$ & $\begin{array}{l}\text { 1) Крихкий матеріал, що додає } \\
\text { значної ваги котушці [10]; } \\
\text { 2) Дорожчі за метали та спла- } \\
\text { ви, особливо при виготовленні } \\
\text { на замовлення [3]. }\end{array}$ \\
\hline \multirow[b]{2}{*}{$\begin{array}{l}\text { Структура } \\
\text { осердя }\end{array}$} & $\begin{array}{l}\text { Плоска } \\
\text { феритова } \\
\text { пластина }\end{array}$ & $\begin{array}{l}\text { 1) Проста у виготовленні і встановленні; } \\
\text { 2) Тонка товщина. }\end{array}$ & $\begin{array}{l}\text { Неоптимізоване використання } \\
\text { площі поверхні осердя (напри- } \\
\text { клад, прямокутне осердя при } \\
\text { круглій котушці). }\end{array}$ \\
\hline & $\begin{array}{l}\text { Осердя } \\
\text { І-типу }\end{array}$ & $\begin{array}{l}\text { 1) Оптимальне використання всієї поверх- } \\
\text { ні осердя; } \\
\text { 2) Простота у виготовленні [18]; } \\
\text { 3) Немагнітний проміжок між осердями } \\
\text { покращує повітряну вентиляцію. }\end{array}$ & $\begin{array}{l}\text { 1) Більша товщина; } \\
\text { 2) Збільшений витік електро- } \\
\text { магнітного поля за межі осердя } \\
\text { [18]; } \\
\text { 3) Складність рівномірного } \\
\text { розміщення. }\end{array}$ \\
\hline \multirow{2}{*}{$\begin{array}{l}\text { Застосу- } \\
\text { вання } \\
\text { осердя }\end{array}$} & Із осердям & $\begin{array}{l}\text { 1) Високий коефіцієнт зв'язку [18]; } \\
\text { 2) Низький витік магнітного потоку; } \\
\text { 3) Зменшений розмір обмотки та кількість } \\
\text { міді; } \\
\text { 4) Поліпшення індуктивності, добротності } \\
\text { та взаємоіндуктивності котушки [18]. }\end{array}$ & $\begin{array}{l}\text { 1) Збільшена маса осердя; } \\
\text { 2) Втрати в осерді та міді [18.] }\end{array}$ \\
\hline & Без осердя & $\begin{array}{l}\text { 1) Висока добротність через незначну змі- } \\
\text { ну індуктивності; } \\
\text { 2) Великий струм через відсутність втрат в } \\
\text { осерді. }\end{array}$ & $\begin{array}{l}\text { 1) Більші розміри котушки; } \\
\text { 2) Велике електромагнітне поле } \\
\text { через витік магнітного потоку; } \\
\text { 3) Вплив на оточуючі металеві } \\
\text { предмети [18]. }\end{array}$ \\
\hline $\begin{array}{l}\text { Екраную- } \\
\text { чий ефект }\end{array}$ & 3 екраном & $\begin{array}{l}\text { 1) Зменшується витік електромагнітного } \\
\text { поля [18]; } \\
\text { 2) Зменшується негативний вплив ЕМІ на } \\
\text { здоров'я людини та навколишній матеріал } \\
\text { [18]; } \\
\text { 2) Проста, надійна та недорога реалізація } \\
\text { [19]. }\end{array}$ & $\begin{array}{l}\text { 1) Може знижуватись ефектив- } \\
\text { ність котушки та збільшуються } \\
\text { втрати [18]; } \\
\text { 2) Може знизитись ефектив- } \\
\text { ність системи на } 1-3 \% \text { [18; } 19] \text {. }\end{array}$ \\
\hline \multirow[b]{2}{*}{$\begin{array}{l}\text { Матеріал } \\
\text { екрану- } \\
\text { вання }\end{array}$} & $\begin{array}{l}\text { Екрану- } \\
\text { вання } \\
\text { феритовою } \\
\text { пластиною } \\
\end{array}$ & $\begin{array}{l}\text { Ядро може ефективно фокусувати магніт- } \\
\text { ний потік та екранувати його[10]. }\end{array}$ & $\begin{array}{l}\text { 1) Більша маса; } \\
\text { 2) Втрати потужності в осерді } \\
\text { (на гістерезис та втрати від } \\
\text { вихрового струму) [18]. }\end{array}$ \\
\hline & $\begin{array}{l}\text { Екрану- } \\
\text { вання } 3 \\
\text { металу } \\
\text { (алюміній) }\end{array}$ & $\begin{array}{l}\text { Легкий і дешевий матеріал для екрануван- } \\
\text { ня [18]. }\end{array}$ & $\begin{array}{l}\text { 1) Не так ефективно зменшує } \\
\text { потік, особливо при високій } \\
\text { частоті; } \\
\text { 2) Втрати потужності в металі } \\
\text { (від вихрового струму та ефек- } \\
\text { ту близькості) [18]. }\end{array}$ \\
\hline
\end{tabular}

3 огляду на перераховані вище переваги, найчастіше використовують круглі котушки з прямокутними або квадратними феритовими осердями. 
Результати проектування і моделювання. Як зазначалося вище, залежно від різної форми котушок та інших геометричних параметрів сильно залежать ефективність передачі та прийому енергії та загальна ефективність системи БПЕ. Ефективність буде різною при однаковій геометрії котушки залежно від значення індуктивності та кількості шарів обмотки котушки.

Концепція використання котушок із низьким значенням індуктивності передбачає використання їх при низьких вхідних напругах та великому струмі. Для цього часто витки роблять із подвійного дроту досить великого діаметра 3 відносно невеликим значенням індуктивності.

У геометрії двошарової котушки також є певні особливості. Двошарова та багатошарова обмотка - це спосіб зменшити зовнішній діаметр котушки. Щоб зовнішній діаметр котушки не перевищував габаритні розміри феритової пластини, у моделі на рис. 2 обмотку укладено у два шари, один над іншим. У свою чергу, кожну обмотку намотано паралельно двома провідниками. Це значно знижує послідовний опір котушок. У цьому випадку перевагою також $є$ те, що кінці й початки обмоток перебувають не в зоні активної передачі енергії і котушки можна розмістити дуже близько між собою. При такому перерізі дроту можливий вхідний і вихідний струм більше 10 А та потужність, що перевищує $100 \mathrm{BT}$, що в заданих геометричних розмірах є чудовим результатом. Забезпеченню досягнення такої потужності сприяє також феритова пластина, що має досить значну товщину 2.5 мм. Осердя успішно замикає потік магнітної індукції, а також служить екраном і радіатором.

Моделювання здійснювалося в програмі ANSYS Electromagnetics Suite. На рис. 2, 8 показана спрощена модель у режимі проектування Eddy current. Зверху розміщені котушки передавача. У корпусі циліндра з необхідними розмірами розміщується обмотка 3 потрібною кількістю витків. Модель котушки покрита циліндричним повітряним об’ємом, радіусом 80 мм і заввишки 160 мм.

У режимі Eddy current котушки можна моделювати з необхідною частотою, бачити значення індуктивності, взаємоіндуктивності, коефіцієнта зв'язку, опору котушок, а також деякі інші параметри [15]. Точність розрахунку індуктивності встановлено на рівні $1 \%$. Відсоток загальної енергетичної похибки попереднього проходу для полів встановлено менше ніж $1 \%$. Було зроблено 10 ітерацій обчислення з обмеженням розміру сітки поверхонь котушок та осердь, для повітряного циліндра встановлена адаптивна сітка. Загальна кількість скінчених елементів становила 85 174. Котушки містять 25 327 елементів, в обох феритових осердях міститься 4684 елементи. Усі інші елементи розташовані в об'ємі немагнітного проміжку.

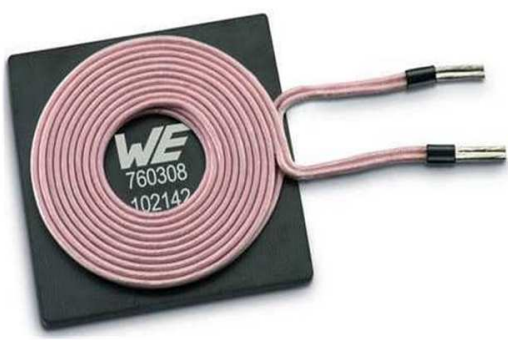

a)

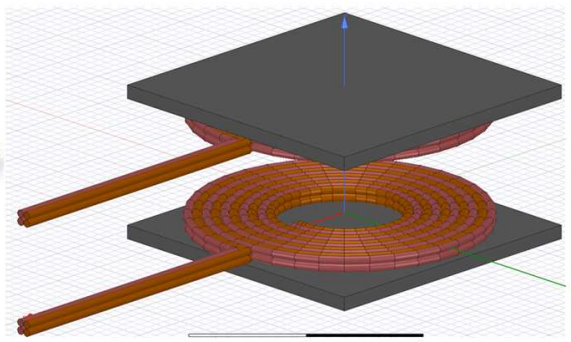

б)

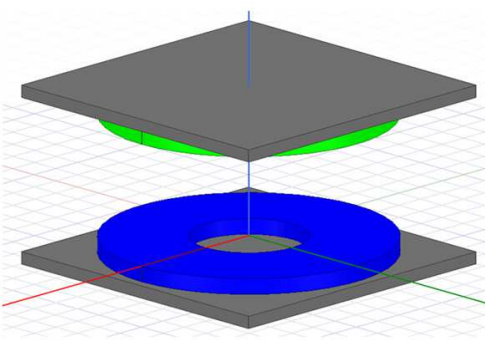

в)

Рис. 2. Котушки індуктивності:

a- промисловий зразок; б-модель у режимі Magnetostatic; в - модель у режсмі Eddy current

Магнітостатична "Magnetostatic" модель (рис. 2, б) це більш точна 3D модель, розроблена в магнітостатичному режимі програми. Ця модель показує, який котушка буде мати вигляд у реальності. $€$ можливість встановлювати відстань між витками, кількість витків, виводи та багато інших параметрів. При цьому значення індуктивності та роз- 
TECHNICAL SCIENCES AND TECHNOLOGIES

поділ магнітної індукції збігаються зі спрощеною моделлю при тих самих геометричних параметрах. У процесі моделювання виникли проблеми з обмеженням обчислювальної потужності комп'ютера та часом моделювання через велику кількість скінчених елементів моделі. Тому перевага була надана спрощеній моделі, що змогла показати необхідні параметри, які далі порівнюються з результатами вимірювань.

Зміну коефіцієнта зв'язку досліджено залежно від відстані між котушками та осьовому зсуві. Таким чином перевіряється фактор, що впливає на ефективність котушок.

На рис. 3 показано залежності коефіцієнта зв'язку від зміни немагнітного проміжку між котушками $(\delta)$ та осьового зсуву $(\Delta)$ при $\delta=1$ мм. Котушки мають прийнятний коефіцієнт зв'язку на невеликій відстані, який повільно зменшується зі збільшенням відстані. Для порівняння, максимальний коефіцієнт зв'язку в раніше розроблених одношарових котушках був більше ніж 0,95 [15]. На рис. 3, a поява від'ємних значень коефіцієнта зв'язку означає зміну напрямку магнітного потоку. Це явище виникає, коли котушки зміщуються відносно одна одної на 50 \% зовнішнього діаметра і більше.

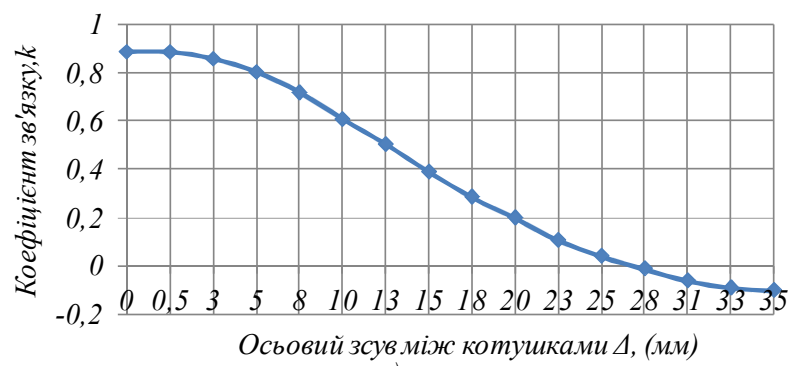

a)

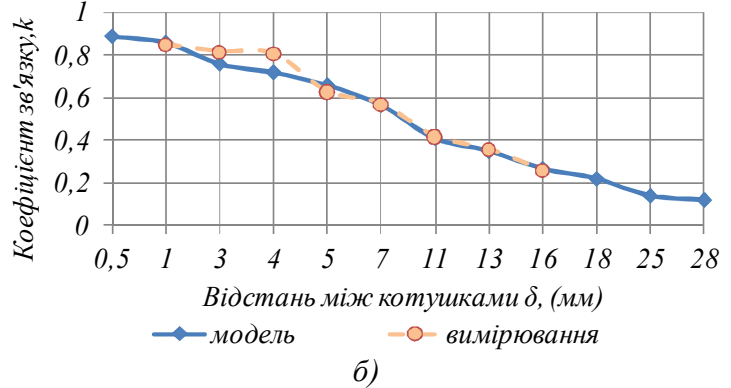

б)

Рис. 3. Залежності коефіцієнта зв'язку при зміні відстані між котушками й осьовому зсуві: $a-k=f(\Delta)$ при $\delta=1$ мм (моделювання); $\sigma-k=f(\delta)$ (моделювання та вимірювання)

Для перевірки результатів моделювання коефіцієнт зв'язку було аналітично визначено при різному немагнітному проміжку між котушками. Для цього котушки зафіксовано на потрібній відстані. Потім окремо виміряно індуктивності обох котушок $\left(L_{l}\right.$ та $\left.L_{2}\right)$, та індуктивність послідовно з'єднаних котушок $\left(L_{12}\right)$. Далі обчислено взаємоіндуктивність М за формулою (1):

$$
M=\frac{\left(L_{12}-L_{1}-L_{2}\right)}{2} .
$$

Відповідно до відомої формули (2) визначено коефіцієнт зв’язку:

$$
k=\frac{M}{\sqrt{L_{1} \cdot L_{2}}} .
$$

Результати моделювання та експерименту на рис. 3, б майже однакові, що вказує на правильність та точність моделі котушки.

Напрямок та інтенсивність магнітного потоку при зміні положення між котушками також важливі. Як видно з розподілу магнітної індукції (рис. 4, a), її величина нерівномірно розподіляється вздовж радіуса котушки, досягаючи найвищого значення на внутрішніх витках $\left(B_{\max }=24,7\right.$ мТл). Спостерігається також невелике розсіювання магнітного потоку за межами магнітної системи. Для його зменшення потрібно зменшити діаметр котушок або збільшити площу фериту. Магнітний потік також добре утримується та спрямовується при осьовому зміщенні котушок (рис. 4, б). 


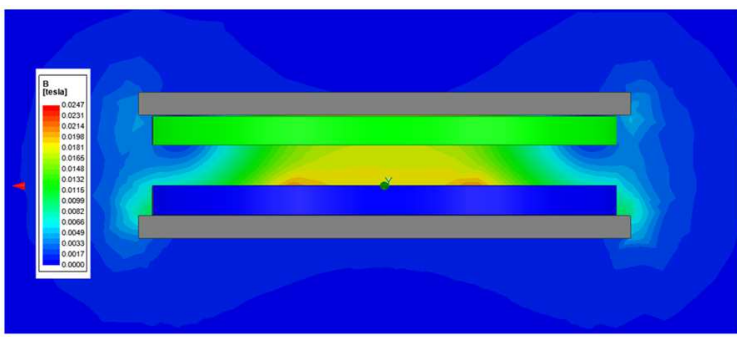

a)
TECHNICAL SCIENCES AND TECHNOLOGIES

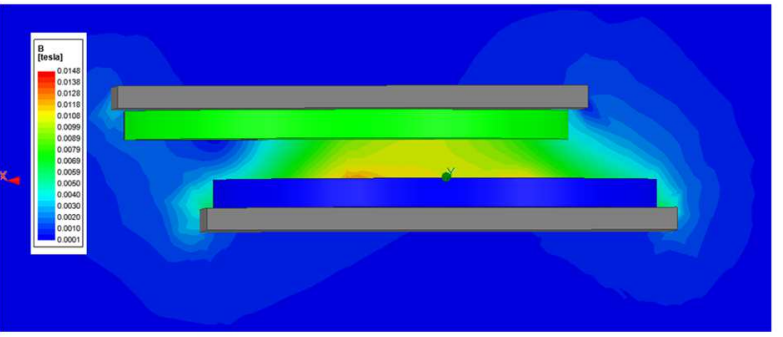

б)

Рис. 4. Поширення потоку магнітної індукиї: a-при відстані між котушками 4,5 мм; б-при осьовому зсуві 10мм та при відстані між котушками 4,5 мм

Отже, дві котушки мають номінальну індуктивність 5,8 мкГн. Виміряні значення на 100 кГц дещо менші, але знаходяться в межах заданої виробником точності. Результати моделювання показали велику схожість параметрів індуктивності з наявними промисловими зразками (табл. 2).

Таблиця 2

Порівняльна таблиця отриманих результатів

\begin{tabular}{|c|c|c|c|c|}
\hline \multirow[b]{2}{*}{ Позначення } & \multirow[b]{2}{*}{ Опис } & \multicolumn{3}{|c|}{ Параметри } \\
\hline & & Модель & $\begin{array}{l}\text { Вимірювання } \\
\text { та інформація } \\
3 \text { документації }\end{array}$ & Відхилення, \% \\
\hline $\mathrm{L}_{1}$ & Котушка 1 (передавальна) & 5,81 мкГн & 5,66 мкГн & $-2,58$ \\
\hline $\mathrm{L}_{2}$ & Котушка 2 (приймальна) & 5,86 мкГн & $5,81 \mathrm{мк} Г \mathrm{н}$ & $-0,86$ \\
\hline $\mathrm{D}$ & Зовнішній діаметр котушки & \multicolumn{2}{|c|}{$50 \mathrm{MM}$} & 0 \\
\hline $\mathrm{d}$ & Внутрішній діаметр котушки & \multicolumn{2}{|c|}{$20 \mathrm{MM}$} & 0 \\
\hline $\mathrm{d}_{\mathrm{w}}$ & Діаметр дроту & \multicolumn{2}{|c|}{$1,4 \mathrm{MM}$} & 0 \\
\hline $\mathrm{L}_{\text {ferr }} \& \mathrm{~W}_{\text {ferr; }} \mathrm{h}_{\text {ferr }}$ & $\begin{array}{c}\text { Довжина,ширина і висота } \\
\text { феритової пластини }\end{array}$ & \multicolumn{2}{|c|}{$53 \times 53 \times 2,5 \mathrm{MM}$} & 0 \\
\hline$\sigma_{\mathrm{w}}, \sigma_{\text {ferr }}$ & $\begin{array}{c}\text { Електрична провідність дроту } \\
\text { i фериту }\end{array}$ & $\begin{array}{c}5,8 \cdot 10^{7} 1 / O_{M M} \\
0,01 / O_{M M}\end{array}$ & - & - \\
\hline$\mu_{\mathrm{r}}$ & $\begin{array}{c}\text { Відносна магнітна } \\
\text { проникність фериту }\end{array}$ & \multicolumn{2}{|c|}{650} & 0 \\
\hline $\mathrm{N}$ & Кількість подвійних витків & \multicolumn{2}{|c|}{10} & 0 \\
\hline $\mathrm{R}$ & Опір котушки & 3,94 мОм & Близько 4 мОм & - \\
\hline
\end{tabular}

За такої двошарової структури потужність передачі може бути збільшена, а активний опір котушки зменшується. Це досягається за рахунок паралельних витків дроту двошарової обмотки. Одночасно зменшується коефіцієнт зв'язку та добротність через зменшення кількості витків. Це призводить до зниження ефективності котушок порівняно зі звичайними одношаровими котушками.

За результатами дослідження основні геометричні та електромагнітні параметри моделі котушок майже збігаються 3 комерційними зразками із точністю не менше як 3 \%.

Висновки відповідно до статті. Ця стаття присвячена порівнянню основних компонентів електромагнітної частини системи для ICПЕ та оцінці точності моделі індуктивних котушок у програмі ANSYS EM Suite за методом скінчених елементів. Визначено переваги котушки круглої форми, осердя прямокутної форми та використання феритового осердя для системи БПЕ.

Виконання такої дослідницької роботи, а саме поєднання моделювання та експериментального вимірювання, дозволило визначити основні електромагнітні параметри двошарових котушок. Двошарові котушки мають такі переваги, як більший максимальний вхідний струм і потужність передачі, менший зовнішній діаметр при заданому значенні індуктивності. Спрощена модель двошарових котушок в ANSYS показала дуже високу наближеність до реальної індуктивності. Точність розрахунку значення індуктивності досягається не менше ніж $3 \%$. 
TECHNICAL SCIENCES AND TECHNOLOGIES

Подяки. Ця наукова робота була підтримана Міністерством освіти і науки України (Гранти № 0117U007260 та №0118U003865) $i$ проектом Україна-Латвія (№ 0119U102105).

\section{Список використаних джерел}

1. Kan T., Nguyen T., White J. C., Malhan R. K., Mi C. C. A New Integration Method for an Electric Vehicle Wireless Charging System Using LCC Compensation Topology: Analysis and Design. I17 Transactions on Power Electronics. Feb. 2017. Vol. 32, no. 2. P. 1638-1650.

2. Bosshard R., Kolar J. W., Wunsch B. Accurate finite-element modeling and experimental verification of inductive power transfer coil design. I17 Applied Power Electronics Conference and Exposition - APEC 2014. Fort Worth. 2014. TX. P. 1648-1653.

3. Knaisch K., Springmann M., Gratzfeld P. Comparison of coil topologies for inductive power transfer under the influence of ferrite and aluminum. 2016 Eleventh International Conference on Ecological Vehicles and Renewable Energies (EVER). Monte Carlo, 2016. P. 1-9.

4. Dai Z., Wang J., Long M., Huang H. A. Witricity-Based High-Power Device for Wireless Charging of Electric Vehicles. Energies. 2017. № 10. P. 323.

5. Ongayo D., Hanif M. Comparison of circular and rectangular coil transformer parameters for wireless Power Transfer based on Finite Element Analysis. 117 13th Brazilian Power Electronics Conference and 1st Southern Power Electronics Conference (COBEP/SPEC). Fortaleza, 2015. P. 1-6.

6. Bosshard R., Kolar J. W., Mühlethaler J., Stevanović I., Wunsch B., Canales F. Modeling and $\eta$ - $\alpha$-Pareto Optimization of Inductive Power Transfer Coils for Electric Vehicles. I17 Journal of Emerging and Selected Topics in PowerElectronics. March 2015. Vol. 3, no. 1. P. 50-64.

7. Valtchev S., Borges B., Brandisky K., Klaassens J. B. Resonant Contactless Energy Transfer With Improved Efficiency. I17 Transactions on Power Electronics. March 2009. Vol. 24, no. 3. P. 685-699.

8. Nicolay P., Lenzhofer M. A Wireless and Passive Low-Pressure Sensor. Sensors. 2014. № 14. P. 3065-3076.

9. Tan L., Li J., Chen C., Yan C., Guo J., Huang X. Analysis and Performance Improvement of WPT Systems in the Environment of Single Non-Ferromagnetic Metal Plates. Energies. 2016. № 9. P. 576.

10. Bosshard R., Muhlethaler J., Kolar J. W., Stevanovic I. Optimized magnetic design for inductive power transfer coils. Proc. 28th APEC. 2013. P. 1812-1819.

11. Zaheer A., Hao H., Covic G. A., Kacprzak D. Investigation of Multiple Decoupled Coil Primary Pad Topologies in Lumped IPT Systems for Interoperable Electric Vehicle Charging. I17 Transactions on Power Electronics. April 2015. Vol. 30, no. 4. P. 1937-1955.

12. Chen W., Liu C., Lee C. H., Shan Z. Cost-Effectiveness Comparison of Coupler Designs of Wireless Power Transfer for Electric Vehicle Dynamic Charging. Energies. 2016. № 9. P. 906.

13. Zuo P., Wu X., Li W., Liu W. Design of wireless energy transfer system based on coupled magnetic resonances. I17 International Conference on Aircraft Utility Systems (AUS). Beijing, 2016. P. 527-532.

14. Zahid Z. U. et al. Design and control of a single-stage large air-gapped transformer isolated battery charger for wide-range output voltage for EV applications. I17 Energy Conversion Congress and Exposition. Denver, CO, 2013. P. 5481-5487.

15. Shevchenko V., Karlov O., Husev O., Kondratenko I., Pakhaliuk B. Coil Design for Wireless Power Transfer with Series-Parallel Compensation. 117 2nd Ukraine Conference on Electrical and Computer Engineering (UKRCON). July, 2019.

16. Cho J., Sun J., Kim H., Fan J., Lu Y., Pan S. Coil design for $100 \mathrm{KHz}$ and $6.78 \mathrm{MHz}$ WPT system :Litz and solid wires and winding methods. I17 International Symposium on Electromagnetic Compatibility \& Signal/Power Integrity (EMCSI). Washington, DC, 2017. P. 803-806.

17. Knaisch K., Gratzfeld P. Comparison of magnetic couplers for inductive electric vehicle charging using accurate numerical simulation and statistical methods. 5th International Electric Drives Production. 2015. P. 1-10.

18. Patil D., McDonough M. K., Miller J. M., Fahimi B., Balsara P. T. Wireless Power Transfer for Vehicular Applications: Overview and Challenges. 117 Transactions on Transportation Electrification. March 2018. Vol. 4, no. 1. P. 3-37.

19. Kim J.et al. Coil Design and Shielding Methods for a Magnetic Resonant Wireless Power Transfer System. Proceedings of the I17. June 2013. Vol. 101, no. 6. P. 1332-1342. 


\author{
Viktor Shevchenko, Igor Kondratenko, Oleksandr Husev, \\ Oleg Khomenko, Kostiantyn Tytelmaier
}

\title{
ESTIMATION OF THE DOUBLE-LAYER COILS MODEL ACCURACY FOR WIRELESS POWER TRANSFER USING FINITE ELEMENT MODELLING
}

Urgency of the research. This topic is actual with increasing demand and interest to the wireless chargers from researchers and users. Target setting. In the development of wireless energy transfer systems it is needed to design inductors with different precision parameters in accordance with the tasks. Therefore, need to know how accurately design an inductor model in one of the popular packages.

Actual scientific researches and issues analysis. Recent works on the various programs used to model electromagnetic processes have been reviewed. From the references about the inductors structure, the necessary information was collected for analysis and comparison.

Uninvestigated parts of general matters defining. Until recently, information on the various structures and inductors components for wireless energy transmission has not been collected and summarized in a comparably convenient in form. The question of the inductor models accuracy in finite element programs has also not enough attention was paid.

The research objective. In order to understand the design object, it is necessary to analyze and compare the structure of the inductors. Then need to evaluate the accuracy of modeling two identical double-layer coils for wireless energy transfer by finite element method in a popular finite element tool.

The statement of basic materials. The structure of inductances, namely coil geometry, shape and material of ferrite core, was analyzed. Their role in the shielding of electromagnetic radiation and the direction of the magnetic induction flux and influence on the value of self-inductance are determined. A simplified model of inductance is developed and its electromagnetic parameters are determined.

Conclusions. The results of double-layer coils modeling are confirmed. Proven that the ANSYS EM Suite is an accurate and reliable tool, and even the simplified inductance models fully meet the requirements of engineers and researchers.

Keywords: wireless power transfer; inductive power transfer; coil geometry; magnetic flux; core shape; shielding; finite element modeling; double-layer coil.

Fig.: 4. Tab.:2. References: 19.

Шевченко Віктор Олександрович - аспірант, асистент кафедри біомедичних радіоелектронних апаратів та систем, Чернігівський національний технологічний університет (вул. Шевченка, 95, м. Чернігів, 14035, Україна).

Shevchenko Viktor - Phd student, assistant of Biomedical Radioelectronic Apparatus and Systems Department, Chernihiv National University of Technology (95 Shevchenka Str., 14035 Chernihiv, Ukraine).

E-mail: shevaip1990@gmail.com

ORCID: https://orcid.org/0000-0001-6201-8693

ResearcherID: R-3688-2018

Scopus Author ID: 57204505187

Кондратенко Ігор Петрович - доктор технічних наук, член-кореспондент НАН України, завідувач відділу електромагнітних систем Інституту електродинаміки НАН України (просп. Перемоги,56, м. Київ, 03057, Україна).

Kondratenko Igor - Doctor of Technical Sciences, Corresponding Member of NAS of Ukraine, Head of the Electromagnetic systems department, Institute of Electrodynamics of NAS of Ukraine (56 Peremohy Av., 03057 Kyiv, Ukraine).

E-mail: $\operatorname{dep} 7 \mathrm{ied}(a, \mathrm{ukr} . n e t$

ORCID: https://orcid.org/0000-0003-1914-1383

Researcher ID: O-4479-2017

Scopus Author ID: 7003332770

Гусев Олександр Олександрович - кандидат технічних наук, доцент, доцент кафедри біомедичних радіоелектронних апаратів та систем, Чернігівський національний технологічний університет (вул. Шевченка, 95, м. Чернігів, 14035, Україна).

Husev Oleksandr - PhD in Technical Sciences, Associate Professor, Associate Professor of Department of Biomedical Radioelectronic Apparatus and Systems, Chernihiv National University of Technology (95 Shevchenka Str., 14035 Chernihiv, Ukraine).

E-mail: oleksandr.husev(a,gmail.com

ORCID: orcid.org/0000-0001-7810-457X

ResearcherID: F-5792-2014

Scopus Author ID: 45861130600

Хоменко Олег Борисович - інженер держбюджетної теми 89/17, Чернігівський національний технологічний університет (вул. Шевченка, 95, м. Чернігів, 14035, Україна).

Khomenko Oleg - engineer of government project 89/17, Chernihiv National University of Technology (95 Shevchenka Str., 14035 Chernihiv, Ukraine).

E-mail: olbor13@gmail.com

Тительмаєр Костянтин Олександрович - старший науковий співробітник держбюджетної теми 91/18, Чернігівський національний технологічний університет (вул. Шевченка 95, м. Чернігів, 14035, Україна).

Tytelmaier Kostiantyn - Senior researcher of government project 91/18, Chernihiv National University of Technology (95 Shevchenka Str., 14035 Chernihiv, Ukraine).

E-mail: kostya.tytelmaier@gmail.com

ORCID: http://orcid.org/0000-0001-7582-0204

ResearcherID: F-4365-2016

Scopus Author ID: 57188715517

Шевченко В., Кондратенко І., Гусев О., Хоменко О., Тительмаєр К. Оцінка точності моделі двошарової котушки індуктивності для бездротової передачі енергії за допомогою методу скінчених елементів. Технічні науки та технології. 2019 . № 3 (17). С. $188-196$. 